Brazilian Journal of Animal Science

ISSN 1806-9290

www.rbz.org.br

\title{
Carcass and meat quality of rabbits fed Tithonia tubaeformis weed
}

\author{
*Corresponding author: \\ sotos@uaeh.edu.mx \\ Received: May 27, 2019 \\ Accepted: October 6, 2019 \\ How to cite: Zepeda-Bastida, A.; Ayala Martínez, \\ M. and Soto Simental, S. 2019. Carcass and meat \\ quality of rabbits fed Tithonia tubaeformis weed. \\ Revista Brasileira de Zootecnia 48:e20190074. \\ https://doi.org/10.1590/rbz4820190074 \\ Copyright: This is an open access article \\ distributed under the terms of the \\ Creative Commons Attribution License \\ (http://creativecommons.org/licenses/by/4.0/) \\ which permits unrestricted use, distribution, \\ and reproduction in any medium, provided the \\ original work is properly cited.
}

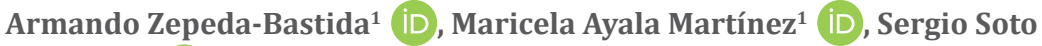 \\ Simental $^{1^{*}}$ iD \\ ${ }^{1}$ Universidad Autónoma del Estado de Hidalgo, Tulancingo, Mexico.
}

\begin{abstract}
The objective of this study was to use different parts of the Tithonia tubaeformis plant in feed for fattening rabbits and then observe the effects on carcass and meat quality. Forty-eight weaned rabbits (35 days of age) were randomly assigned to four groups ( $\mathrm{n}=12$ by treatment). Animals were fed ad libitum a control diet as well as three experimental diets, with addition of Tithonia tubaeformis leaves, whole plant, and stems. Rabbits were slaughtered after 63 days of age without fasting. Results indicate that live weight (0.917), skin (0.79), feet (6.679), and lumbar circumference of the carcass (0.707) have higher positive correlations with hot carcass. There were no significant differences between treatments for all variables measured, except for kidneys and kidney fat. $\mathrm{pH}$ and color values were different among treatments. The results indicate that Tithonia tubaeformis leaves or the whole plant could be added to feed for growing rabbits.
\end{abstract}

Keywords: color, invasive plant, meat, texture

\section{Introduction}

Rabbit meat has several advantages over other meats due to its fatty acids profile, high protein content, several vitamins and minerals, and low cholesterol and sodium contents (Para et al., 2015). However, rabbit meat has low consumption per capita and, consequently, production is low. There are some problems associated with rabbit production, including the cost of feed, as well as digestive complications, especially with fattening rabbits, which affect productive parameters, e.g., daily gain, feed intake, among other factors. The use of plants in feed is an area that has been gaining interest over the past few years with regard to rabbit production research, as plants contain bioactive compounds that can improve carcass and meat quality (Cardinali et al., 2015; Kone et al., 2016). The use of nutritional antioxidants in livestock systems is considered the key to improve rabbit production (Elwan et al., 2019). Several healthy plants have been used for feeding fattening rabbits, as they are a source of phytochemicals used as antioxidants or antimicrobials (Zeng et al., 2015; Dalle Zotte et al., 2016). Bilberry pomace was used as a feeding strategy to improve fatty acid content in rabbit meat (Dabbou et al., 2017). Cardinali et al. (2015) used oregano, rosemary, and vitamin $\mathrm{E}$ as feed supplements for enhancing growth performance and carcass traits in fattening rabbits. Kone et al. (2016) used onion, cranberry, strawberry, and their extracts as feed supplements to increase productive performance and meat quality.

An invasive plant is considered as an exotic species in an ecosystem (Richardson and Pysek, 2006). However, when a native species changes environment and is permitted to colonize new areas and become dominant, it can be considered as an invasive species (Valéry et al., 2008). The genus Tithonia is widely distributed in Mexico and Central America and has eleven recognized species divided in two groups: annual and perennial 
plants. Tithonia tubaeformis is an annual herbaceous plant with stems from 1 to $3 \mathrm{~m}$, round, with colors ranging from yellow to brown, alternate leaves ranging in size from 2 to $11 \mathrm{~cm}$, and stalks from 10 to $45 \mathrm{~cm}$. The flowering season is from August to November (Duke, 1982). This plant is an annual weed, which grow mainly in maize cultures, and is considered problematic as it grows after rainy seasons (Ochoa Martinez et al., 1999), providing competition for soil nutrients (Sánchez-Blanco and Guevara-Féfer, 2013).

There is no evidence that Tithonia tubaeformis has been used for feeding rabbits, but García et al. (2016) found this plant in the diet composition of grazing goats in a xerophilous scrub. The leaves of Tithonia tubaeformis are used in traditional medicine to alleviate skin problems (Gheno-Heredia et al., 2011), while Bello-Gonzalez et al. (2015) found that the cooked flowers of this plant can be used to improve digestive problems in humans. Molina-Mendoza et al. (2012) identified Tithonia tubaeformis as a medicinal plant and part of floristic composition in Huasca, Hidalgo, Mexico. Nevertheless, Hinojosa Dávalos et al. (2013) studied properties of this plant using methanol:water extracts and found mainly pirogalic and cathecol as phytochemical compounds and an anti-inflammatory response. The use of this plant in feed for fattening rabbits leads to an increase in productive performance, carcass traits, and meat quality and is influenced by the secondary metabolites that are stored in different concentrations in the plant.

The objective of this study was to use different parts of the Tithonia tubaeformis plant for feeding fattening rabbits to observe effects on carcass and meat quality.

\section{Material and Methods}

Animals used in this trial were housed in an experimental rabbit station in Tulancingo, Hidalgo, Mexico (Latitude $20^{\circ} 06^{\prime}$ and Longitude $98^{\circ} 38^{\prime}$ ). The institutional committee on animal use (case no. 002/18) approved the care and management of rabbits.

Forty-eight weaned rabbits ( $35 \mathrm{~d}$ ) were randomly assigned to four treatments (two replicates of six animals each). Rabbits ( $\mathrm{n}=6$ per cage) were housed in cages $(90 \times 60 \mathrm{~cm})$ adapted with manual feeders and automatic drinkers. The average temperature inside the house was $20^{\circ} \mathrm{C}$. The breeds used were crosses of New Zealand, California, and English Pot $(\mathrm{NZ} \times \mathrm{C} \times \mathrm{EP})$ with an average weight of $1165.52 \pm 124.06 \mathrm{~g}$. Feed was pelletized using a pellet machine model SKJ120 (Shandong, China). Isoproteic (16\% of crude protein) and isoenergetic (2.3 Mcal. $\mathrm{kg}^{-1}$ of digestible energy) experimental diets were formulated according to the methods used by De Blas and Mateos (2010) and were offered to the animals. Nutrient requirements were obtained from NRC (1977) tables. This study was performed with four treatments: control and Tithonia tubaeformis leaves, stems, and whole plant (Table 1).

The weed was obtained in the Mezquital Valley in Hidalgo State in the center of Mexico, from a maize cultivation field. After transportation to the lab, the plant was separated into leaves, stems, and whole plant and dried at room temperature for five days in the shadow. All parts were ground using a miller (Mexicana de Suministros Agropecuarios SA de CV, Tulancingo, Hidalgo, México) and a 5-mm diameter sieve. Once ground, the weed was stored in a dark plastic container until use, and a proximal analysis was determined (crude protein - 8.3, 19.6, 4.3; ash - 5.93, 14.17, 4.05; ether extract - 8.3, 19.6, 4.3; crude fiber - 33.1, 8.1, 46.7; neutral detergent fiber - 60.43, 20.5, 61.52; and acid detergent fiber - 24.84, 8.82, 42.94) for whole Tithonia tubaeformis plant, leaves, and stems, respectively).

Rabbits were slaughtered at $63 \mathrm{~d}$ of age in the facilities of the meat laboratory in Tulancingo, Hidalgo, Mexico, without being previously subjected to fasting. The animals were stunned and processed according to national legislation (NOM-033-SAG/ZOO-2014). Once rabbits were slaughtered, they were dissected to obtain hot carcasses, liver, kidney, digestive system, bladder, and skin. The empty body weight was calculated minus the gastrointestinal and bladder content to determine the live weight of rabbits. Carcasses were then stored in refrigeration at $4{ }^{\circ} \mathrm{C}$ for $24 \mathrm{~h}$. The dorsal and carcass length of the animals were determined by measuring from the atlas to the last ischia vertebra. The pelvis and lumbar circumference of the animal and carcass were measured using a measuring tape.

The carcasses were sectioned after $24 \mathrm{~h}$ of refrigerated storage as indicated by Blasco et al. (1993). The head was cut at the atlas level, the forequarter was obtained by cutting between sixth and seventh ribs, the thoracic cage was determined by cutting the last rib, and the loin was attained in sixth and seventh 
Table 1 - Ingredient composition of the experimental diets

\begin{tabular}{|c|c|c|c|c|}
\hline \multirow{2}{*}{ Item } & \multicolumn{4}{|c|}{ Treatment $^{1}$} \\
\hline & Control & Leaves & Stems & Whole plant \\
\hline \multicolumn{5}{|l|}{ Ingredient ( $\mathrm{g} \mathrm{kg}^{-1}$ of dry matter) } \\
\hline Alfalfa & 102 & 0 & 0 & 0 \\
\hline Barley straw & 101 & 100 & 107 & 92 \\
\hline Corn & 200 & 182 & 192 & 170 \\
\hline Bran wheat & 65 & 65 & 65 & 65 \\
\hline Soybean husk & 108 & 108 & 108 & 108 \\
\hline Soybean meal & 170 & 180 & 161 & 201 \\
\hline Canola meal & 39 & 39 & 40 & 39 \\
\hline Sorghum & 179 & 179 & 179 & 179 \\
\hline Molasse & 10 & 10 & 10 & 10 \\
\hline Vitamin and mineral premix & 25 & 25 & 25 & 25 \\
\hline Tithonia tubaeformis & 0 & 112 & 113 & 112 \\
\hline \multicolumn{5}{|l|}{ Calculated composition } \\
\hline Crude protein (\%) & 16 & 16 & 16 & 16 \\
\hline Crude fiber (\%) & 13 & 13 & 13 & 13 \\
\hline Digestible energy (Mcal/kg) & 2.5 & 2.5 & 2.5 & 2.5 \\
\hline Neutral detergent fiber (\%) & 25.9 & 26.4 & 26.7 & 26.3 \\
\hline Acid detergent fiber (\%) & 16.5 & 16.4 & 17 & 16.8 \\
\hline $\mathrm{Ca}(\%)$ & 0.8 & 0.8 & 0.8 & 0.8 \\
\hline $\mathrm{P}(\%)$ & 0.2 & 0.2 & 0.2 & 0.2 \\
\hline
\end{tabular}

${ }^{1}$ Control and treatments with Tithonia tubaeformis leaves, stems, and whole plant.

lumbar vertebrae by cutting the abdominal wall transversally to the vertebral column to eventually obtain the foreleg. All these parts were weighed separately.

Meat color was measured on the loin surface at room temperature $\left(22^{\circ} \mathrm{C}\right)$ using a portable colorimeter i-Lab S560 (Microptix, Wilton, Maine, USA). The values were recorded in terms of CIELab color space using an Illuminant D65 $2^{\circ}$ standard observer as indicated in American Meat Science Association meat color measurement guidelines (AMSA, 2012) using lightness $\left(\mathrm{L}^{*}\right)$, redness $\left(\mathrm{a}^{*}\right)$, and yellowness $\left(\mathrm{b}^{*}\right)$ values. pH was determined using a pH meter for meat Hanna model HI99163 (Hanna instruments, Cluj-Napoca, Romania). Water holding capacity was measured according to the method described by Honikel (1987). Cooking losses were measured in loins, and samples were put into a plastic bag and cooked at $80^{\circ} \mathrm{C}$ until reaching an internal temperature of $68^{\circ} \mathrm{C}$. Cooked samples were cooled at room temperature and then weighed, while cooking loss values were calculated by differences in weight before and after cooking and expressed as a percentage. Once samples were cooled, a texture profile analysis was carried out following the method described by Bourne (1978). Six cubes (1 cm each side) for each loin were used, and samples were cut parallel to muscle fibers. The texture analyzer Brookfield model CT3 (Brookfield, Middleboro, MA, USA) was set to compression at $50 \%$ of the sample and perpendicular to the muscle fiber direction using $1 \mathrm{~mm} \cdot \mathrm{s}^{-1}$ of crosshead speed. A TA3/1000 probe and a TA-BT-KIT base were used. The samples were compressed twice, and force-time curves of deformation were obtained through Texture Pro CT software, which produced hardness, resilience, cohesiveness, and springiness values.

Pearson's correlation coefficients were calculated using the PROC CORR procedure from the SAS software (Statistical Analysis System, version 9.0) to determine the relationship between morphometric measurements and carcass quality. Carcass traits and meat quality variables were analyzed by least squares following the General Lineal Model procedure using SAS software. The statistical model used was:

$$
\mathrm{Y}_{\mathrm{ij}}=\mu+\beta_{\mathrm{i}}+\varepsilon_{\mathrm{ij}}
$$

in which $Y_{\mathrm{ij}}=$ dependent variable, $\mu$ = mean of the variable, $\beta_{\mathrm{i}}=$ fixed effect of $\mathrm{i}$-th rabbit of the group, and $\varepsilon_{\mathrm{ij}}=$ experimental error associated with the observation $\mathrm{Y}_{\mathrm{ij}}$. When statistical differences were found $(\mathrm{P}<0.05)$ a Tukey comparison test was used. 


\section{Results}

Animal morphometric measures are correlated to carcass characteristics (Table 2), and all variables were significant, except hip circumference of the carcass (HCC). Live weight (0.917), skin (0.79), foot (0.58), and lumbar circumference of the carcass (0.707) had higher positive correlations with hot carcass. These results suggest that these indicators were the best predictors of hot carcass weight. It is possible that live weight associated with lumbar circumference carcass should be used to obtain carcass weight. It could, therefore, be used to classify rabbit carcass into several classes according to meat quality.

The carcass quality of fattening rabbits fed Tithonia tubaeformis (Table 3) had no significant differences $(\mathrm{P}>0.05)$ among treatments, except for kidneys and kidney fat. Rabbits fed the whole plant showed an

Table 2 - Correlation coefficients between live animal and carcass morphometric measurements in fattening rabbits fed Tithonia tubaeformis

\begin{tabular}{lccccccccc}
\hline Parameter & LAL & LAC & LALC & S & F & CL & HCC & LC & HC \\
\hline LW & $0.589^{* *}$ & $0.576^{* *}$ & $0.650^{* *}$ & $0.806^{* *}$ & $0.580^{* *}$ & $0.548^{* *}$ & 0.137 & $0.671^{* *}$ & $0.917^{* *}$ \\
LAL & & $0.407^{* *}$ & $0.443^{* *}$ & $0.554^{* *}$ & 0.298 & $0.321^{*}$ & 0.144 & $0.423^{* *}$ & $0.490^{* *}$ \\
LAC & & & $0.739^{* *}$ & $0.521^{* *}$ & 0.177 & $0.364^{*}$ & 0.066 & $0.429^{* *}$ & $0.531^{* *}$ \\
LALC & & & & $0.548^{* *}$ & 0.223 & $0.354^{*}$ & 0.002 & $0.497^{* *}$ & $0.571^{* *}$ \\
S & & & & & $0.487^{* *}$ & $0.583^{* *}$ & 0.281 & $0.652^{* *}$ & $0.790^{* *}$ \\
F & & & & & & 0.033 & 0.161 & $0.473^{* *}$ & $0.679^{* *}$ \\
CL & & & & & & & 0.097 & $0.514^{* *}$ & $0.514^{* *}$ \\
HCC & & & & & & & & 0.180 & 0.159 \\
LCC & & & & & & & & & $0.707^{* *}$ \\
\hline
\end{tabular}

LW - live weight; LAL - live animal length; LAC - live animal circumference; LALC - live animal lumbar circumference; S - skin; F - foot; CL - carcass length; HCC - hip circumference of the carcass; LC - lumbar circumference; HC - hot carcass. Significant correlation ${ }^{* *} \mathrm{P}<0.01 ;{ }^{*} \mathrm{P}<0.05$.

Table 3 - Carcass quality of rabbits fed different parts of Tithonia tubaeformis plant

\begin{tabular}{|c|c|c|c|c|}
\hline \multirow{2}{*}{ Variable } & \multicolumn{4}{|c|}{ Treatment $^{1}$} \\
\hline & Leaves & Whole plant & Control & Stems \\
\hline Empty body weight (EBW; g) & $1919.40 \pm 91.36$ & $2046.83 \pm 254.47$ & $1931.12 \pm 298.84$ & $2098.00 \pm 197.39$ \\
\hline Dressing percentage (\%) & $60.07 \pm 2.33$ & $60.48 \pm 4.00$ & $59.86 \pm 2.68$ & $60.07 \pm 1.34$ \\
\hline Viscera (g.kg-1 EBW) & $245.33 \pm 43.88$ & $260.67 \pm 32.50$ & $247.17 \pm 49.55$ & $235.86 \pm 12.76$ \\
\hline Full gastrointestinal tract weight (g) & $187.31 \pm 35.19$ & $193.85 \pm 27.61$ & $183.59 \pm 40.44$ & $177.19 \pm 5.55$ \\
\hline Full bladder (g.kg ${ }^{-1}$ EBW) & $5.46 \pm 3.26$ & $2.67 \pm 0.77$ & $5.33 \pm 3.79$ & $3.98 \pm 2.14$ \\
\hline Heart (g.kg-1 EBW) & $3.22 \pm 0.61$ & $3.09 \pm 0.38$ & $2.79 \pm 0.39$ & $3.03 \pm 0.32$ \\
\hline Lungs (g.kg-1 EBW) & $5.98 \pm 1.27$ & $5.90 \pm 1.84$ & $7.77 \pm 1.28$ & $8.24 \pm 1.77$ \\
\hline Spleen (g.kg-1 EBW) & $0.73 \pm 0.30$ & $0.49 \pm 0.06$ & $0.59 \pm 0.22$ & $0.48 \pm 0.04$ \\
\hline Liver (g.kg ${ }^{-1}$ EBW) & $37.42 \pm 16.25$ & $45.34 \pm 5.43$ & $41.88 \pm 12.25$ & $37.35 \pm 9.03$ \\
\hline Kidneys (g.kg-1 EBW) & $6.12 \pm 1.14 \mathrm{~b}$ & $8.15 \pm 2.63 a$ & $6.67 \pm 1.39 b$ & $6.37 \pm 0.55 b$ \\
\hline Empty gastrointestinal tract weight (g) & $83.05 \pm 12.10$ & $95.64 \pm 9.41$ & $87.88 \pm 11.51$ & $85.67 \pm 3.51$ \\
\hline Empty bladder (g.kg ${ }^{-1}$ EBW) & $2.82 \pm 0.92$ & $1.74 \pm 0.56$ & $1.99 \pm 0.87$ & $2.13 \pm 0.83$ \\
\hline Cold carcass yield (\%) & $631.82 \pm 33.43$ & $632.17 \pm 46.54$ & $609.52 \pm 30.11$ & $631.13 \pm 16.03$ \\
\hline Kidney fat (g.kg-1 EBW) & $16.60 \pm 3.92 \mathrm{a}$ & $10.35 \pm 4.04 \mathrm{~b}$ & $13.38 \pm 4.21 \mathrm{ab}$ & $12.90 \pm 1.04 \mathrm{ab}$ \\
\hline Scapular fat weight (g. $\mathrm{kg}^{-1} \mathrm{EBW}$ ) & $4.63 \pm 2.01$ & $4.94 \pm 1.58$ & $3.89 \pm 1.80$ & $4.71 \pm 1.86$ \\
\hline Head (g.kg-1 EBW) & $60.50 \pm 5.69$ & $60.80 \pm 8.03$ & $62.51 \pm 6.99$ & $61.98 \pm 7.23$ \\
\hline Fore part weight (g.kg ${ }^{-1}$ EBW) & $154.07 \pm 13.06$ & $156.37 \pm 13.11$ & $145.86 \pm 9.78$ & $156.33 \pm 7.91$ \\
\hline Intermediate part weight (g.kg-1 EBW) & $71.51 \pm 7.70$ & $69.69 \pm 11.72$ & $62.46 \pm 5.83$ & $67.21 \pm 4.08$ \\
\hline Hind part weight (g.kg-1 EBW) & $110.88 \pm 7.84$ & $111.16 \pm 11.76$ & $117.93 \pm 9.96$ & $116.19 \pm 8.30$ \\
\hline
\end{tabular}

${ }^{1}$ Control and treatments with Tithonia tubaeformis leaves, stems, and whole plant.

a,b - Different letters within rows indicate a significant difference among treatments using Tukey's test $(\mathrm{P}<0.05)$ 
increase in kidney weight, but lower levels of fat. These effects were significant, since using leaves or the stem of this plant should result in a leaner carcass.

Meat quality parameters detected in rabbits fed Tithonia tubaeformis (Table 4), in particular $\mathrm{pH}$ and color values, were different $(\mathrm{P}<0.05)$ among treatments, while the $\mathrm{pH}$ value was lower in the stem treatment.

Hardness was lower in meat of rabbits fed the whole Tithonia tubaeformis plant. Resilience was higher $(\mathrm{P}<0.01)$ in samples of cooked meat from rabbits fed leaves and whole plant. Moreover, cohesiveness and springiness were higher $(\mathrm{P}<0.01)$ in meat from animals fed Tithonia tubaeformis leaves. These results are important as the whole plant produces a tender meat and is more resilient than other treatments. It is possible that Tithonia tubaeformis has molecules that soften rabbit meat, although other studies would be necessary to determine this. The hardness value indicates that the meat of animals fed the whole Tithonia tubaeformis plant or leaves showed less resistance to cutting than other treatments, including the control group.

Table 4 - Meat quality of fattening rabbits fed different parts of Tithonia tubaeformis plant

\begin{tabular}{lcccc}
\hline \multirow{2}{*}{ Parameter } & \multicolumn{3}{c}{ Treatment $^{1}$} \\
\cline { 2 - 4 } & Leaves & Whole plant & Control & Stems \\
\hline Legs (g) & $208.15 \pm 15.41$ & $211.01 \pm 17.71$ & $202.48 \pm 9.04$ & $204.65 \pm 6.91$ \\
Meat (g.kg-1 of leg) & $765.08 \pm 21.49$ & $737.73 \pm 40.21$ & $743.83 \pm 26.94$ & $739.90 \pm 61.64$ \\
Bone $\left({\mathrm{g} \cdot \mathrm{kg}^{-1} \text { of leg) }}\right.$ & $214.48 \pm 22.44$ & $214.33 \pm 20.31$ & $223.40 \pm 33.76$ & $229.54 \pm 47.73$ \\
Fat (g.kg ${ }^{-1}$ of leg) & $6.43 \pm 3.46$ & $5.85 \pm 3.15$ & $10.45 \pm 2.73$ & $10.97 \pm 3.46$ \\
pH & $5.84 \pm 0.08 \mathrm{a}$ & $5.83 \pm 0.07 \mathrm{a}$ & $5.81 \pm 0.06 \mathrm{a}$ & $5.75 \pm 0.04 \mathrm{~b}$ \\
Water holding capacity (\%) & $21.39 \pm 5.53$ & $24.09 \pm 7.36$ & $22.98 \pm 6.31$ & $22.14 \pm 6.32$ \\
L $^{*}$ & $57.14 \pm 3.89 \mathrm{~b}$ & $57.94 \pm 5.23 \mathrm{ab}$ & $57.64 \pm 3.66 \mathrm{~b}$ & $59.89 \pm 3.75 \mathrm{a}$ \\
$\mathrm{a}^{*}$ & $-0.30 \pm 1.23 \mathrm{~b}$ & $0.67 \pm 1.71 \mathrm{a}$ & $-0.34 \pm 1.12 \mathrm{~b}$ & $-0.80 \pm 1.15 \mathrm{~b}$ \\
$\mathrm{~b}^{*}$ & $8.34 \pm 2.24 \mathrm{bc}$ & $8.99 \pm 2.52 \mathrm{ab}$ & $10.16 \pm 2.65 \mathrm{a}$ & $7.65 \pm 2.84 \mathrm{c}$ \\
Cooking loss (\%) & $16.14 \pm 4.05$ & $16.97 \pm 6.67$ & $17.94 \pm 4.85$ & $15.38 \pm 3.88$ \\
Hardness (N) & $6.13 \pm 1.96 \mathrm{bc}$ & $5.49 \pm 2.77 \mathrm{c}$ & $7.51 \pm 2.52 \mathrm{ab}$ & $7.61 \pm 2.79 \mathrm{a}$ \\
Resilience & $0.18 \pm 0.05 \mathrm{a}$ & $0.17 \pm 0.05 \mathrm{a}$ & $0.11 \pm 0.05 \mathrm{~b}$ & $0.12 \pm 0.05 \mathrm{~b}$ \\
Cohesiveness & $0.47 \pm 0.06 \mathrm{a}$ & $0.43 \pm 0.07 \mathrm{~b}$ & $0.35 \pm 0.07 \mathrm{c}$ & $0.39 \pm 0.08 \mathrm{bc}$ \\
Springiness & $2.33 \pm 0.31 \mathrm{a}$ & $2.20 \pm 0.36 \mathrm{ab}$ & $2.07 \pm 0.48 \mathrm{~b}$ & $2.05 \pm 0.38 \mathrm{~b}$ \\
\hline
\end{tabular}

${ }^{1}$ Control and treatments with Tithonia tubaeformis leaves, stems, and whole plant.

a,b - Different letters within rows indicate a significant difference among treatments using Tukey's test $(\mathrm{P}<0.05)$.

\section{Discussion}

A correlation coefficient should be used to deduce carcass quality, mainly live weight, skin, foot, and lumbar circumference. These measurements produced higher positive correlation coefficients in this study. It is possible to use the variables live weight (0.91), skin (0.79), and foot (0.68) to predict hot carcass weight because they have the highest correlation coefficients, although it would be important to perform another statistical analysis to confirm this assumption. However, Yalçin et al. (2006) reported a negative correlation between lumbar circumference and carcass length. Nevertheless, Mousa-Balabel et al. (2017) found moderate positive correlations between body weight and tail length, head length and tail length, and chest girth and ear length in New Zealand rabbits. Moreover, Akinsola et al. (2014) described a high positive correlation between body weight and linear body measurements, particularly body weight and chest girth (0.939). Rabbit linear measurement should be used for predicting carcass quality and for choosing animals for meat production in selected markets. Singh et al. (2015) used spirulina (5\%) and thyme (3\%) as feed supplements for fattening rabbits, but they did not improve 
body measurements, except for abdominal girth gain during a period of eight weeks. Anhita et al. (2016a) concluded that using azolla as feed supplement at 1.5 and $3 \%$ in diets did not affect growth performance in broiler rabbits after feeding for 12 weeks.

Supplementation of diets with natural additives from the plants containing bioactive molecules have shown promising results in improving carcass traits and meat quality (Alagawany et al., 2019). Carcass characteristics are used to determine carcass yield. As previously mentioned, the results indicate that there were no differences among treatments in carcass quality. Dressing percentage was approximately $60 \%$ in all treatments. Kidney weight was higher in the group consuming whole plants, but the other groups were similar to the control treatment, which may be due to a part of the plant having a chemical compound that affects this organ. Adebayo et al. (2009) reported a high tolerance to Thitonia diversifolia aqueous extract for seven days in rats; however, Fakunle and Abatan (2007) found significant changes in hematological, biochemical, and histopathological parameters in rats after $14 \mathrm{~d}$ of experiment. It is likely that adverse changes in organs depend on time of feeding with this plant, but some histological studies should be conducted to verify these findings. Nonetheless, Tithonia tubaeformis leaves or stems could be used in rabbit feeding. Meanwhile, Anhita et al. (2016b) reported that the inclusion of fresh azolla in broiler rabbit feed for 12 weeks did not affect carcass traits, organs, or chemical composition of meat. Some studies have demonstrated that the use of Silybum marianum (Cullere et al., 2016), Amaranthus dubius (Molina et al., 2018), and Lythrum salicaria (Kovitvadhi et al., 2016) in feed does not affect rabbit carcass quality. The use of all these plants had no recorded negative impact on carcass quality, but in all cases, the authors suggested using them as dietary supplements for growing rabbits. It is possible that these suggestions were influenced by cost, as they help to produce a low-cost rabbit feed.

The intake of Tithonia tubaeformis suggests an increase in kidney fat weight in the group consuming leaves, but a decrease in the group fed the whole plants as feed. The leaves of this plant could be utilized for feeding rabbits because all carcass characteristics are similar to the control group, and some of them are slightly higher, e.g., dressing percentage, chilled carcass, and weights of fore and intermediate parts of the carcass. These findings are similar to those reported by Fathi et al. (2019), who found that eucalyptus leaves did not affect dressing and fore or hind parts of the rabbit carcass. Similar results were found in slaughter traits of rabbits fed diet supplemented with ginger powder (Mancini et al., 2018), quebracho and chestnut (Mancini et al., 2019), or garlic and turmeric powder (Alagawany et al., 2016) as growth promoters.

Some weeds can be used to feed animals, and Tithonia tubaerformis could be one of them. This weed is usually a competition for cultivated plants such as maize and should be used for rabbit feeding, but its influence on meat quality is limited because almost all traits were similar. Meat weight was slightly

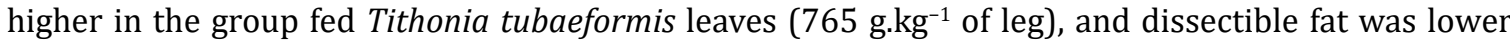
in this group (6.43 g.kg-1 of leg) compared with the control. Larzul and Gondret (2005) stated that meat:bone ratio is a good predictor of meat content in carcass, while Molina et al. (2018) reported a good meat yield independently of amaranth inclusion levels in the diet. However, North et al. (2018) demonstrated that quercetin inclusion increases meat:bone ratio, maybe because quercetin decreases bone weight by altering bone structure.

There are many factors that modify the $\mathrm{pH}$ of rabbit meat, such as breed, carcass cooling rate, preslaughter handling, feeding conditions, and muscle localization (Hulot and Ouhayoun, 1999). In this study, as previously indicated, groups fed diets supplemented with Tithonia tubaeformis leaves and stems have higher $\mathrm{pH}$ values than the control or whole-plant group. These results may be influenced by antioxidant compounds found in the different parts of the plant. Hinojosa Dávalos et al. (2013) reported that Tithonia tubaeformis contains antioxidant compounds such as phenols and flavonoids. Some studies reported that $\mathrm{pH}$ was not affected by diets supplemented with ginger powder (Mancini et al., 2018), quercetin (North et al., 2018), Amarantus dubius (Molina et al., 2018), and quebracho and chestnut tannin mix (Mancini et al., 2019). However, Cullere et al. (2016) added Silybum marianum to rabbit feed and found an increase in $\mathrm{pH}$ values, which is supposedly linked to glycolytic metabolism in the muscle intermediated by silibinin presence in Silybum marianum.

R. Bras. Zootec., 48:e20190074, 2019 
Meat color is affected by animal diet, which in turn modifies the metabolism, glycogen storage, $\mathrm{pH}$, and antioxidant accumulation (Mancini, 2013). As previously mentioned, $\mathrm{pH}$ was influenced by Tithonia tubaeformis. Lightness $\left(\mathrm{L}^{*}\right)$, redness $\left(\mathrm{a}^{*}\right)$, and yellowness $\left(\mathrm{b}^{*}\right)$ values were modified when this plant was supplemented to rabbits. The presence of antioxidant compounds such as phenols and flavonoids in this plant could be responsible for differences in color in this study. Papuc et al. (2017) mentioned that polyphenols present in plant extracts or byproducts preserve meat color better than synthetic antioxidants used in meat and meat products. Simonová et al. (2010) found no significant differences in color parameters ( $\mathrm{L}^{*}$ and $\mathrm{b}^{*}$ ). Volek et al. (2018) reported non-significant differences in $\mathrm{pH}$ and meat color of rabbits fed white lupin seed. Mancini et al. (2018) observed an increase in $\mathrm{L}^{*}$ and $\mathrm{b}^{*}$ when ginger powder was supplemented to rabbits. However, North et al. (2018) fed rabbits quercetin and did not find any differences among the groups regarding color parameters. Similar results were found by Koné et al. (2019), using an oil extract from a mix of different plants. Other studies did not find differences in color when feeding diets containing barley, wheat, or corn dried distillers grains (Alagón et al., 2015) or billberry pomace (Dabbou et al., 2017).

The meat texture profile analysis demonstrated that supplementation with Tithonia tubaeformis has a significant effect compared with control diet. The treatment of whole plants produced a softer rabbit meat compared with the other groups. These results suggest that this plant contains a compound that affects meat hardness. Hernández-Martínez et al. (2018) found that hardness and gumminess of rabbit meat decrease when sorghum is replaced by hydrolyzed sorghum, suggesting that it is due to an increase in nutrient synthesis and assimilation.

Hernández-Martínez et al. (2018) found that hardness and gumminess of rabbit meat decrease when sorghum is replaced by hydrolyzed sorghum, suggesting it is due to an increase in the nutrient synthesis and assimilation. However, Alagón et al. (2015) used diets containing barley, wheat, or corn dried distillers grains for growing rabbits, and no differences among treatments were found for meat texture analyzed with Warner-Bratzler blade.

\section{Conclusions}

Tithonia tubaeformis is a weed plant that is scarcely used for feeding animals, and could be used for fattening rabbits since carcass and meat quality parameters were similar among control and treatments. The use of whole plant or leaves produces tender meat than the control diet. All of these values indicate that Tithonia tubaeformis leaves or whole plant could be added to growing rabbit feed. Feed costs could be reduced, since it is a commonly found weed.

\section{Conflict of Interest}

The authors declare no conflict of interest.

\section{Author Contributions}

Conceptualization: A. Zepeda-Bastida, M. Ayala Martínez and S. Soto Simental. Data curation: M. Ayala Martínez and S. Soto Simental. Formal analysis: A. Zepeda-Bastida and S.S. Simental. Investigation: A. Zepeda-Bastida and M. Ayala Martínez. Methodology: M. Ayala Martínez and S. Soto Simental. Project administration: A. Zepeda-Bastida. Supervision: A. Zepeda-Bastida and S. Soto Simental. Validation: S. Soto Simental. Visualization: M. Ayala Martínez and S. Soto Simental. Writing-original draft: A. Zepeda-Bastida, M. Ayala Martínez and S. Soto Simental. Writing-review \& editing: S. Soto Simental.

\section{Acknowledgments}

The authors would like to thank the PRODEP program for providing financial support to this work. Project number DSA/103.5/16/10281. SEP-PFCE 2018. 


\section{References}

Adebayo, J. O.; Balogun, E. A. and Oyeleke, S. A. 2009. Toxicity study of the aqueous extract of Tithonia diversifolia leaves using selected biochemical parameters in rats. Pharmacognosy Research 1:143-147.

Akinsola, O. M.; Nwagu, B. I.; Orunmuyi, M.; Iyeghe-Erakpotobor, G. T.; Eze E. D.; Abanikannda, O. T. F.; Onaadepo, O. E. U.; Okud, E. U. and Louis, U. 2014. Prediction of bodyweight from body measurements in rabbits using principal component analysis. Annals of Biological Sciences 2:1-6.

Alagawany, M.; Ashour, E. A. and Reda, F. M. 2016. Effect of dietary supplementation of garlic (Allium sativum) and turmeric (Curcuma longa) on growth performance, carcass traits, blood profile and oxidative status in growing rabbits. Annals of Animal Science 16:489-505.

Alagawany, M.; Elnesr, S. S. and Farag, M. R. 2019. Use of liquorice (Glycyrrhiza glabra) in poultry nutrition: Global impacts on performance, carcass and meat quality. World's Poultry Science Journal 75:293-304. https://doi. org/10.1017/S0043933919000059

Alagón, G.; Arce, O.; Serrano, P.; Ródenas, L.; Martínez-Paredes, E.; Cervera, C.; Pascual, J. J. and Pascual, M. 2015. Effect of feeding diets containing barley, wheat and corn distillers dried grains with solubles on carcass traits and meat quality in growing rabbits. Meat Science 101:56-62. https://doi.org/10.1016/j.meatsci.2014.10.029

AMSA - American Meat Science Association. 2012. Meat color measurement guidelines. Champaign, IL, USA.

Anhita, K. C.; Rajeshwari, Y. B.; Prabhu, T. M.; Vivek Patil, M.; Shilpa Shree,J. and Anupkumar, P. K. 2016a. Effect of supplementary feeding of azolla on growth performance of broiler rabbits. ARPN Journal of Agricultural and Biological Science 11:30-36.

Anhita, K. C.; Rajeshwari, Y. B.; Prabhu, T. M.; Devarnvadagi, A. S.; Rohith, K. J. and Shilpa Shree, J. 2016b. Carcass and meat quality traits of broiler rabbits when supplement with azolla. Journal of Experimental Zoology 19:417-420.

Bello-González, M. A.; Hernández-Muñoz, S.; Lara-Chávez, M. B. N. and Salgado-Garciglia, R. 2015. Plantas útiles de la comunidad indígena nuevo San Juan Parangaricutiro, Michoacán, México. Polibotánica 39:175-215.

Blasco, A.; Ouhayoun, J. and Masoero, G. 1993. Harmonization of criteria and terminology in rabbit meat research. World Rabbit Science 1:3-10. https://doi.org/10.4995/wrs.1993.189

Bourne, M. C. 1978. Texture profile analysis. Food Technology 35:62-66.

Cardinali, R.; Cullere, M.; Dal Bosco, A.; Mugnai, C.; Ruggeri, S.; Mattioli, S.; Castellini, C.; Trabalza Marinucci, M. and Dalle Zotte, A. 2015. Oregano, rosemary and vitamin E dietary supplementation in growing rabbits: Effect on growth performance, carcass traits, bone development and meat chemical composition. Livestock Science 175:83-89. https://doi.org/10.1016/j.livsci.2015.02.010

Cullere, M.; Dalle Zotte, A.; Celia, C.; Renteria-Monterrubio, A. L.; Gerencsér, Zs.; Szendrő, Zs.; Kovács, M.; Kachlek, M. L. and Matics, Zs. 2016. Effect of Silybum marianum herb on the productive performance, carcass traits and meat quality of growing rabbits. Livestock Science 194:31-36. https://doi.org/10.1016/j.livsci.2016.10.012

Dabbou, S.; Renna, M.; Lussiana, C.; Gai, F.; Rotolo, L.; Kovitvadhi, A.; Brugiapaglia, A.; Helal, A. N.; Schiavone, A.; Zoccarato, I. and Gasco, L. 2017. Bilberry pomace in growing rabbit diets: effects on quality traits of hind leg meat. Italian Journal of Animal Science 16:371-379. https://doi.org/10.1080/1828051X.2017.1292413

Dalle Zotte, A.; Celia, C. and Szendro, Zs. 2016. Herbs and spices inclusion as feedstuff or additive in growing rabbit diets and as additive in rabbit meat: a review. Livestock Science 189:82-90. https://doi.org/10.1016/j.livsci.2016.04.024

De Blas, C. and Mateos, G. G. 2010. Feed formulation. p.222-232. In: Nutrition of the rabbit. 2nd ed. de Blas, C. and Wiseman, J., eds. Cab International, Wallingford, UK.

Duke, J. C. 1982. Revision of Tithonia. Rhodora 84:453-522.

Elwan, H. A. M.; Elnesr, S. S.; Mohany, M. and Al-Rejaie, S. S. 2019. The effects of dietary tomato powder (Solanum lycopersicum L.) supplementation on the haematological, immunological, serum biochemical and antioxidant parameters of growing rabbits. Journal of Animal Physiology and Animal Nutrition 103:534-546. https://doi.org/10.1111/jpn.13054

Fakunle, J. O. and Abatan, M. 0. 2007. The toxicological effects of aqueous leaf extract of Tithonia diversifolia gray in rats. Journal of Animal and Veterinary Advances 6:1223-1226.

Fathi, M.; Abdelsalam, M.; Al-Homidan, I.; Ebeid, T.; Shehab-El-Deen, M.; Abd El-Razik, M.; Abou-Emera, O. and Mostafa M. 2019. Supplemental effects of eucalyptus (Eucalyptus camaldulensis) leaves on growth performance, carcass characteristics, blood biochemistry and immune response of growing rabbits. Annals of Animal Science 19:779-791. https://doi.org/10.2478/aoas-2019-0023

García, S.; Santos, R. E.; Posadas, C.; Morón, F. J. and Rosales, C. A. 2016. Composición de la dieta de cabras en pastoreo en un matorral xerófilo. In: Perspectivas y avances de la producción animal en México. Lee Rangel, H. A.; Ramírez Tobías, H. M.; Roque Jimenez, J. A., eds. Universitaria Potosina, SLP, México.

Gheno-Heredia, Y. A.; Nava-Bernal, G.; Martínez-Campos, A. R. and Sánchez-Vera, E. 2011. Las plantas medicinales de la organización de parteras y médicos indígenas tradicionales de Ixhuatlancillo, Veracruz, México y su significancia cultural. Polibotánica 31:199-251

R. Bras. Zootec., 48:e20190074, 2019 
Hernández-Martínez, C. A.; Treviño-Cabrera, G. F.; Hernández-Luna, C. E.; Silva-Vázquez R.; Hume, M. E.; Gutiérrez-Soto, G. and Méndez-Zamora, G. 2018. The effects of hydrolysed sorghum on growth performance and meat quality of rabbits. World Rabbit Science 26:155-163. https://doi.org/10.4995/wrs.2018.7822

Hinojosa Dávalos, J.; Gutiérrez Lomelí, M.; Siller López, F.; Rodríguez Sahagún, A.; Morales Del Río, J. A.; Guerrero Medina, P. J. and Del Toro Sánchez, C. L. 2013. Screening fitoquímico y capacidad antiinflamatoria de hojas de Tithonia tubaeformis. Biotecnia 15:53-60.

Honikel, K. O. 1987. How to measure the water-holding capacity of meat? Recommendation of standardized methods. In: Evaluation and control of meat quality in pigs. Current Topics in Veterinary Medicine and Animal Science, vol. 38. Tarrant P. V.; Eikelenboom, G. and Monin, G., eds. Springer, Dordrecht, Germany.

Hulot, F. and Ouhayoun, J. 1999. Muscular pH and related traits in rabbits: a review. World Rabbit Science 7:15-36. https://doi.org/10.4995/wrs.1999.378

Kone, A. P.; Cinq-Mars, D.; Desjardins, Y.; Guay, F.; Gosselin, A. and Saucier, L. 2016. Effects of plant extracts and essential oils as feed supplements on quality and microbial traits of rabbit meat. World Rabbit Science 24:107-119. https://doi.org/10.4995/wrs.2016.3665

Koné, A. P.; Desjardins, Y.; Gosselin, A.; Cinq-Mars, D.; Guay, F. and Saucier, L. 2019. Plant extracts sand essential oil product as feed additives to control rabbit meat microbial quality. Meat Science 150:111-121. https://doi. org/10.1016/j.meatsci.2018.12.013

Kovitvadhi, A.; Gasco, L.; Ferrocino, I.; Rotolo, L.; Dabbou, S.; Malfatto, V.; Gai, F.; Peiretti, P. G.; Falzone, M.; Vignolini, C.; Cocolin, L. and Zoccarato, I. 2016. Effect of purple loosestrife (Lythrum salicaria) diet supplementation in rabbit nutrition on performance, digestibility, health and meat quality. Animal 10:10-18. https://doi.org/10.1017/S1751731115001822

Larzul, C. and Gondret, F. 2005. Aspects génétiques de la croissance et de la qualité de la viande chez le lapin. INRA Productions Animales 18:119-129.

Mancini, R. 2013. Meat color. p.177-198. In: The science of meat quality. Kerth, C. R., ed. Wiley-Blackwell, Ames, IO, USA. https://doi.org/10.1002/9781118530726.ch9

Mancini, S.; Moruzzo, R.; Minieri, S.; Turchi, B.; Cerri, D.; Gatta, D.; Sagona, S.; Felicioli, A. and Paci, G. 2019. Dietary supplementation of quebracho and chestnut tannins mix in rabbit: effects on live performances, digestibility, carcass traits, antioxidant status, faecal microbial load and economic value. Italian Journal of Animal Science 18:621-629. https://doi.org/10.1080/1828051X.2018.1549514

Mancini, S.; Secci, G.; Preziuso, G.; Parisi, G. and Paci, G. 2018. Ginger (Zingiber officinale Roscoe) powder as dietary supplementation in rabbit: life performances, carcass characteristics and meat quality. Italian Journal of Animal Science 17:867-872. https://doi.org/10.1080/1828051X.2018.1427007

Molina, E.; González-Redondo, P.; Moreno-Rojas, R.; Montero-Quintero, K. and Sánchez-Urdaneta, A. 2018. Effect of the inclusion of Amaranthus dubius in diets on carcass characteristics and meat quality of fattening rabbits. Journal of Applied Animal Research 46:218-223. https://doi.org/10.1080/09712119.2017.1287078

Molina-Mendoza, J. L.; Galván-Villanueva, R.; Patiño-Siciliano, A. and Fernández-Nava, R. 2012. Plantas medicinales y listado florístico preliminar del Municipio de Huasca de Ocampo, Hidalgo, México. Polibotánica 34:259-291.

Mousa-Balabel, T. M.; El-Sheikh, R. A. and El-Nenny, N. S. 2017. Prediction of Californian rabbits body weight from their body characteristics in Egypt. Life Science Journal 14:52-56.

NOM-033-SAG/ZOO-2014. 2015. Norma Oficial Mexicana. Métodos para dar muerte a los animales domésticos y silvestres. Available at: <http://www.economia-noms.gob.mx/normas/noms/2010/033sagzoo2015.pdf>. Accessed on: Feb. 01, 2019.

North, M. K.; Dalle Zotte, A. and Hoffman, L. C. 2018. The effects of quercetin supplementation on New Zealand white grower rabbit carcass and meat quality - A short communication. Meat Science 145:363-366. https://doi.org/10.1016/j. meatsci.2018.07.014

NRC - National Research Council. 1977. Nutrient requirements of rabbits. 2nd rev. ed. National Academic Press, Washington, DC, USA.

Ochoa Martinez, D. L.; Zavaleta-Mejía, E.; Mora-Aguilera, G. and Johansen, R. M. 1999. Implications of weed composition and thrips species for the epidemiology of tomato spotted wilt in chrysanthemum (Dendranthema grandiflora). Plant Pathology 48:707-717. https://doi.org/10.1046/j.1365-3059.1999.00397.x

Papuc, C.; Goran, G. V.; Predescu, C. N.; Nicorescu, V. and Stefan, G. 2017. Plant polyphenols as antioxidant and antibacterial agents for shelf-life extension of meat and meat products: Classification, structures, sources, and action mechanisms. Comprehensive Reviews in Food Science and Food Safety 16:1243-1268. https://doi.org/10.1111/1541-4337.12298

Para, P. A.; Ganguly, S.; Wakchaure, R.; Sharma, R.; Mahajan, T. and Praveen, P. K. 2015. Rabbit has the potential of being a possible alternative to other meats as a protein source: A brief review. International Journal of Pharmacy and Biomedical Research 2:17-19.

Richardson, D. M. and Pyšek, P. 2006. Plant invasions: merging the concepts of species invasiveness and community invasibility. Progress in Physical Geography: Earth and Environment 30:409-431. https://doi. org/10.1191/0309133306pp490pr 
Sánchez-Blanco, J. and Guevara-Féfer, F. 2013. Plantas arvenses asociadas a cultivos de maíz de temporal en suelos salinos de la ribera del lago de Cuitzeo, Michoacán, México. Acta Botánica Mexicana 105:107-129.

Simonová, M. P.; Chrastinová, Ĺ; Mojto, J.; Lauková, A.; Szabóová, R. and Rafay, J. 2010. Quality of rabbit meat and phytoadditives. Czech Journal of Food Sciences 28:161-167.

Singh, N.; Gulati, H. K.; Sihag, S.; Dalal, D. S.; Kapoor, P. K. and Malik, A. K. 2015. Effect of spirulina (Arthrospira platensis) and thyme (Thymus vulgaris) supplementation on growth performance of rabbits. Haryana Veterinarian 54:117-120.

Valéry, L.; Fritz, H.; Lefeuvre, J. C. and Simberloff, D. 2008. In search of a real definition of the biological invasion phenomenon itself. Biological Invasions 10:1345-1351. https://doi.org/10.1007/s10530-007-9209-7

Volek, Z.; Bureš, D. and Uhlířvá, L. 2018. Effect of dietary dehulled white lupine seed supplementation on the growth, carcass traits and chemical, physical and sensory meat quality parameters of growing-fattening rabbits. Meat Science 141:50-56. https://doi.org/10.1016/j.meatsci.2018.03.013

Yalçin, S.; Onbaşilar, E. E. and Onbaşilar, İ. 2006. Effect of sex on carcass and meat characteristics of New Zealand White rabbits aged 11 weeks. Asian-Australasian Journal of Animal Science 19:1212-1216. https://doi.org/10.5713/ajas.2006.1212

Zeng, Z.; Zhang, S.; Wang, H. and Piao, X. 2015. Essential oil and aromatic plants as feed additives in non-ruminant nutrition: a review. Journal of Animal Science and Biotechnology 6:7. https://doi.org/10.1186/s40104-015-0004-5 